\title{
WHEN IS IT GOOD TO STEAL? A MORAL REFLECTION ON CURRENT TRENDS IN INTELLECTUAL PROPERTY
}

\author{
J.J. Britz, S.R. Ponelis \\ Britz is with the School of Information Studies, University of Wisconsin-Milwauke, USA and \\ Ponelis is with the ${ }^{2}$ School of Information Technology, University of Pretoria, South Africa
}

\begin{abstract}
This paper explores the role of intellectual property rights in the distribution of information in the marketplace. It is argued that the current trends in IP legislation bring an imbalance between access to scholarly information and its control. It is further argued that scholarly information is essential in nature and that people cannot be excluded from it. It therefore poses a moral concern. Based on the work of John Rawls general guidelines are proposed that can be used directly by policymakers with regard to the fair distribution of scholarly information in the marketplace.
\end{abstract}

\section{INTRODUCTION}

Intellectual property rights (IPRs) constitute a legal mechanism to make information excludable, i.e. to legally protect the economic value of information. Information plays an important role in the education of members of a society. A major source of information for this purpose are scholarly publications, the intellectual property rights of which are generally held by the publishers of the journals. The increasingly stricter control of access exercised by these publishers on scholarly information gives rise to a moral question, namely, is the extent of the high pricing of scholarly information justifiable? It is well known that many scholars, particularly in the developing world, cannot afford access to scholarly journals. The moral question is even more applicable to information that is electronically 
available - considering that the marginal cost of electronic information is nearly zero.

In order to answer the aforementioned question, the paper will be structured as follows: first, we will provide a broad introduction to the problem, namely the imbalance between access to and control of intellectual property; second, the moral concerns will be discussed together with the associated complexity of moral reasoning; and last, general guidelines will be formulated based on the Rawlian perspective of social justice.

\subsection{Control of Versus Access to Information}

Information has played an increasingly important role in several economies, particularly in those of industrialized countries. Given this development in these economies, information has increasingly become a commodity; as a result, the value of information is of paramount importance. The value that information can have varies and the same information can have more than one type of value, which is determined by its use. Broadly speaking, these kinds of value can be related to either the domain of common or public good, or to private good. The kinds of value together with the applicable category are indicated in Table 1.

Table 1: Kinds of value of information (from Lor and Britz, 2005)

\begin{tabular}{|c|c|c|}
\hline $\begin{array}{l}\text { Competitive } \\
\text { value }\end{array}$ & $\begin{array}{l}\text { Lies in possessing information that others do not } \\
\text { (yet) have that can be exploited to gain a livelihood } \\
\text { or competitive advantage. }\end{array}$ & $\begin{array}{l}\text { Private } \\
\text { good }\end{array}$ \\
\hline $\begin{array}{l}\text { Instrumental } \\
\text { value }\end{array}$ & $\begin{array}{l}\text { Found in the application of information to improve } \\
\text { the capacity of humankind to cope with the } \\
\text { environment. }\end{array}$ & \multirow{5}{*}{$\begin{array}{l}\text { Common } \\
\text { or public } \\
\text { good }\end{array}$} \\
\hline $\begin{array}{l}\text { Accumulative } \\
\text { value }\end{array}$ & $\begin{array}{l}\text { Lies in being used to build upon the contributions of } \\
\text { others in order to create and generate new } \\
\text { information. }\end{array}$ & \\
\hline $\begin{array}{l}\text { Educational } \\
\text { value }^{1}\end{array}$ & $\begin{array}{l}\text { Equipping successive generations of humans to } \\
\text { improve the quality of their lives and the quality of } \\
\text { their environment. }\end{array}$ & \\
\hline $\begin{array}{l}\text { Cultural } \\
\text { value }\end{array}$ & $\begin{array}{l}\text { Strengthening the cohesion of communities and } \\
\text { societies/enhancing the quality of communal living. }\end{array}$ & \\
\hline $\begin{array}{l}\text { Transcendent } \\
\text { value }\end{array}$ & $\begin{array}{l}\text { Relates to satisfaction of aesthetic, religious, spiritual } \\
\text { or higher needs, i.e., non-material quality of life. }\end{array}$ & \\
\hline
\end{tabular}

${ }^{1}$ Closely linked to accumulative value for the educational value of information enables accumulative value. 
Information, furthermore, has certain characteristics that distinguish it from other economic goods, namely:

- An information good must be used or consumed in order to demonstrate the good and to determine the associated value;

- Information goods are typically non-rival (that is, one person's consumption does not diminish another's ability to consume the same information good) and sometimes non-excludable (that is, one person's consumption cannot exclude another person from consuming the information - or as Barlow (1993) put it: "information can be transferred without leaving the possession of the original owner"); and

- The cost structure of information goods comprises a high fixed cost but low variable and marginal costs (Varian, 1998).

The atypical cost structure of information goods in competitive markets results in the price of information goods tending to zero since these markets drive prices towards marginal costs. In order to counter this, the competitive value must be protected so that the act of creation of information in economies and societies can be supported and stimulated through compensation for creation. This is done legally by means of the concept of intellectual property (IP) and intellectual property rights (IPRs).

Intellectual property is defined as a means of acquiring ownership over a particular resource that is intangible in nature and usually involves the protection of some of invention that is created by the human mind. As such IP includes music, novels, medicines, computer software and products obtained from the use of indigenous knowledge (Prakash, 1999). Du Plessis (1999) defines intellectual property as incorporeal or intangible property that comes into existence through the mental or intellectual activity and creativity of a person; once created, the property has an independent existence separate from and outside of the person of the creator and has commercial value and thus merits legal protection. IPRs are traditionally divided into statutory and common law rights, with the former constituting the majority of the rights. These comprise the four major categories: patents, trade marks, industrial designs and copyright. Other IPRs include plant breeders' rights, heraldic rights and performers' rights (Du Plessis, 1999).

Scholarly publication is a major source of information creation. Compensation in the scholarly arena goes to the publishers who hold the copyright to the journals, and in the case of other academic publications in which academic work is presented, compensation is shared rather then going to the authors (although authors are sometimes paid a modest amount). However the authors, are funded either by their institutions, governments, 
research institutions, normally but not exclusively in the form of grants ${ }^{2}$. Upon examination of the major scholarly publishers it is clear that handsome profits are to be had by these information intermediaries: In 2003 Reed Elsevier's pre-tax profits totalled $£ 222$ million compared with $£ 216$ million the previous year (Sabbagh, 2004). In addition, Sabbagh (2004) reports that Elsevier also proposed a $5.5 \%$ price increase because it was "increasing the content it was producing and investing in new electronic features." The UK's Commons Science and Technology Committee furthermore reported that the price of scientific publications had increased by $58 \%$ since 1998 and accuses Reed Elsevier of "not being transparent" about its costs and "ripping off the academic community" (Sabbagh, 2004), which is in essence a captive audience.

Information contained in scholarly publications plays a vital role in education. Education is seen as having a positive ancillary social value for a society (Bates, 1988). Bates (1988) is of the opinion that where ancillary social value is concerned, real-life markets do not seem economically efficient nor generate maximum social welfare thus resulting in sub-optimal markets. According to him it will threaten the sustainability of informationbased societies and contribute to the digital divide and widen the gap between the so-called information 'haves' and the 'have-nots'.

Shapiro and Varian (1998) noted that the unique and atypical cost structure of information leads to a propensity for monopolies to be created in the marketplace. Most countries try to prevent monopolistic tendencies since control of a market results in the very real possibility for prices to be set without much or any cognizance being taken of the market's willingness (or ability) to pay. Having the economic control in the scholarly publishing industry therefore makes it far more likely for prices to be beyond the reach of those in developing countries, who are unable to pay the prices thus set, due to unfavourable exchange rates, etc.

It is important to note that the recognition and application of IPRs per se is not being disputed. Based on the Lockeian labour theory and the Hegelian personality theory it is argued that individuals have property rights and that this extends to intangible IPRs. These rights need to be protected by government and individuals have the right to benefit from them. As

2 "Generally applicable to basic or sometimes applied research, it is based on the principle of cost reimbursement rather than on the value of the output since the form of new knowledge can obviously not be predicted. To manage costs, monitoring and performance is usually built in" (Ponelis and Britz, 2004). 
Hamelink (1999:158) correctly points out, intellectual property regimes are developed to:

- Protect the moral rights of authors (moral justification);

- Recognize and protect the right to fair compensation for the creation and distribution of information goods (economic justification); and

- Enhance, to the benefit of the common good, the creation and accessibility of new knowledge (social justification).

It is, however, clear from the above that there is a tension between control and access ${ }^{3}$ : publishers need to control distribution of information in order to protect their interests but access to scholarly information is needed for education and development. The increase in pricing of scholarly publications led to the marginalization of many scholars and even from preventing them access to information. IPRs in effect is allowing the private good to partially eclipse the common or public good, as depicted in Error! Reference source not found. This increasing imbalance in the tension between control and access gives rise to a moral question which begs for a moral response.

\section{Figure 1: The private good's partial eclipse of the common/public good}

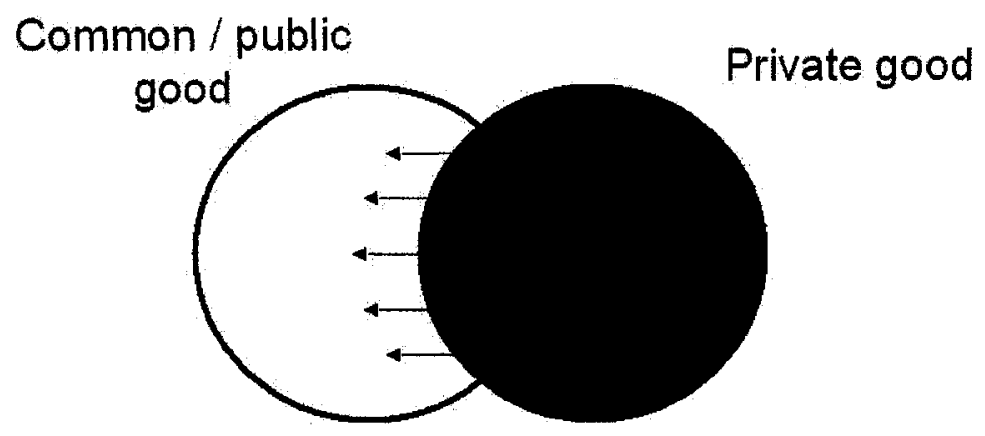

3 Access does not also imply accessibility; accessibility is a broader concept and encompasses, for example, understanding the language in which information is conveyed, sharing the context in which it is created, etc. The argument here is about access and not accessibility. 


\section{COMPLEX NATURE OF THE MORAL ARGUMENT}

The moral response to this tension is complicated by the complexity of the moral argument. There are a number of factors that contribute to the complex nature, namely:

Complexity of information-Information can be used for many different purposes, for example, education at primary, secondary and tertiary levels; entertainment; and marketing. Educational use differs from entertainment and marketing in the sense that it can be considered as essential information. It can be argued that the paradigm for legal protection of information should be based on the uses of information rather than on the control of the making of copies (Branscomb, 1994:6) and that information considered essential should be treated differently in terms of IPRs.

Publishers argue that they need to cover costs of production-but is it acceptable to push all these costs to the end-user/consumer? Several movements, for example, copyleft and the Creative Commons (and its offshoot the Scientific Commons) aim to make electronic information available freely to end-users under a number of licensing arrangement; the costs of production is borne by the author(s), thereby preventing entry into the private good domain by means of IPRs legislation. Both scientific authors and their funding bodies are also increasingly endeavouring to provide freer access to scholarly information, with the medical sciences acting as pioneers - possibly a result of the controversial nature of denial of access leading to loss of, if not lives, then at least quality of lives in both developed and developing countries. For example, in the medical sciences, the National Institute of Health (NIH) in the United States requires all publications of research to which it had contributed funds be made available for free one year after publication in a journal. Although journal publishers are not pleased about this, refusing to comply could well result in the loss of around 60,000 papers annually, many of which are considered to be the best in the field (The Economist, 2005). There are also a number of electronic peer-reviewed academic journals that charge authors to publish and make content available to end-users at no cost; these journals are being included on Thomson's ISI listings.

Instrumental, accumulative and educational value of information eroded-Higher education institutions, in a bid to increase ever-decreasing funding from traditional sources are attempting to move their scholarly research outputs out of the common good domain into the private good 
domain through IPRs in order to benefit financially. For example, Columbia University patented a process, the validity of which is now being disputed by seven biotechnology firms in the United States (The Economist, 2004). As a result the traditional "experimental use" exception for non-commercial research granted to universities to bypass IPRs compensation is also being challenged.

Economic choices-End-users make choices in terms of consumption based on their priorities. For example, many students have a mobile phone but argue that textbooks are too expensive to buy. Price is an economic mechanism through which resources are allocated as such is a measurement or function of the value that a consumer places on the good exchanged (Du Toit, 1994; Rowley, 1997). According to Rowley (1997), price plays a central role in the availability and access to information goods. IPRs provide the legal instruments to protect these economic interests.

Price discrimination exists when sales of identical goods are transacted at different prices from a single vendor. Vendors use price discrimination for a variety of reasons. A customer may have to pay more if the seller determines that he or she is willing to - for example, because of the customer's wealth, carelessness, lack of knowledge, or eagerness to buy. The practice of taking advantage of a state of imbalance between two (or possibly more) markets where price discrimination is exercised is called arbitrage. Sellers of goods and services often attempt to prohibit or discourage arbitrage. ${ }^{4}$

Discouraging arbitrage entails either keeping the different price groups separate, making price comparisons difficult, or restricting pricing information; these mechanisms result in a boundary between segments known as a rate fence. With e-commerce on the Internet, however, it is easy to compare prices from different vendors or the same vendor in different geographic locations and to make an economically prudent buying decision, thereby eroding the effectiveness of the rate fence. For example, students in the United States regularly buy textbooks from the book retailer Amazon's UK website for $£ 40$ rather than for US\$80 on the US website 6 . Using price discrimination as a mechanism to ensure access to information goods to developing countries may result in a similar situation arising.

\footnotetext{
${ }^{4}$ Note that over time arbitrage tends to reduce price discrimination through, for example, adjustments in exchange rates for currency.

${ }^{5}$ URL http://www.amazon.co.uk

${ }^{6}$ URL http://www.amazon.com
} 
Global trade requires control-agreements such as the World Trade Organization's (WTO) Trade-Related Aspects of Intellectual Property Rights (TRIPS) and bodies like the World Intellectual Property Organization (WIPO) are necessary to regulate global trade, but who is advantaged and who disadvantaged through the exercise of control? Branscomb (1994) is of the opinion that information technology can be used as a solution to offer universal access, but she expresses doubt as to the collective will worldwide to do so. Poor developing countries are voiceless with regard to decisions that directly affect them although there are efforts to counter this, for example, the proposal by a number of developing countries including Brazil and Argentina with regard to a new development agenda on IP (WIPO, 2004).

By using simulation, Maxwell (2004) showed that "the same policy options have different effects depending on the condition of the publishing industry at any stage of development." For example, during the early stages of development, adequate capitalization is far more critical than the recognition of copyright. This is contrary to the view advocated by many in favour of strong copyright protection in developing countries saying that it is beneficial to development because it attracts overseas capital investment (Maskus, 2000): strong international IPRs may in fact impair the developing countries' ability to develop local publishing capability, thus slowing the growth and health of publishing and authorship in these countries. Maxwell's model therefore suggests that "developing country trade protectionism, coupled with moderate copyright protection and initial price controls, might be more beneficial to the development of domestic publishing in Third World countries" which is of course heavily opposed by the US and WIPO. As Barlow (1993) has stated, laws developed prior to consensus in a society usually favour the already established few who get them passed and not society as a whole.

Progression in knowledge production determine a country's response to $\boldsymbol{I P}$-Varian (1998) indicates the positive relationship between per capita income in a country and recognition of IPRs: as the demand for local content increases when consumers have more disposable income, the protection of local as well as other content is increasingly recognised in order to stimulate creation. This has been the case in India. Thus, overall economic security should automatically result in recognition for IPRs but in its absence, one can expect there to be little incentive to create information goods or to respect the IP of others. 
IP is based on individual property rights, a hallmark of the Western intellectual tradition; China (Lara, 1998) and countries in Africa do not have an inherent culture of IP and therefore of its protection. Confucianism and the emphasis on the good of society at the expense of personal reward gives rise to the notion in China that it is an honour to copy someone's work (Lara, 1998); however, Chinese cultural conceptions as justification for industrial scale piracy in China are not as easily defended nor accepted.

Lehman (2002) is one among many who argue that developing countries must use IPRs as a tool for economic growth; but if the concept is culturally alien, is it possible for them to do so without any assistance from outside which again raises the question of dependence or whether it is acceptable to expect them to do so? Furthermore, the nature of indigenous knowledge (IK), which is a valuable source for development and scientific research, is frequently such that it does not allow for protection by IPRs, since for example, it may not meet the criteria of uniqueness, or of having an identified creator or author, etc.

If one accepts Maxwell's conclusions from his simulation on the effects of IPRs in a society, then some interesting questions arise: are the IPRs enforced on developing countries appropriate to the state of development of their respective publishing industries? In other words, will sufficient new creators join the marketplace to reach the critical mass necessary for Varian's argument to hold true? And, if the publishing industries in developed countries are indeed mature and if aggressive market expansion into developing countries is advised, will this not flood the developing countries markets with culturally alien goods (which again raises the question of access as opposed to accessibility)? Again, there is a tension between access to the private good and destruction of cultural diversity as common good.

UNESCO's Convention on the Protection of the Diversity of Cultural Contents and Artistic Expressions aims to allow countries to implement policies that foster cultural diversity. However, some governments have proposed revisions that would transform this Convention into an instrument that further extends corporate ownership of culture. The US is particularly concerned that the Convention might be used to support trade barriers against it. The Communication Rights in the Information Society (CRIS) campaign points out that references to IPRs (private good) protection in the Convention must be balanced with protection of the cultural commons (common good), which is not currently the case. Negotiations are continuing on various aspects of this Convention (Media Trade Monitor, 2005). 


\section{USING RAWLS' PRINCIPLES OF SOCIAL JUSTICE TO DEVELOP GENERAL GUIDELINES}

According to Britz (1999) justice viewed from an Aristotelian perspective can be broadly defined as giving a person or group what they deserve. Justice has a two-fold objective: preventing harm and demanding treatment that is respectful of humanity. As such it can be said to be a virtue of a moral agent. Rawls re-established social justice in contemporary moral reasoning in his work Theory of Justice (1973) and is of the opinion that justice is "the first virtue of social institutions, as truth is in systems of thought" (Rawls, 1973).

Rawls views justice as fairness and argues for the fair distribution of social goods in a society. Approaching justice as fairness is necessary to ensure that the basic rights and liberties of all are protected and that should social and economic inequalities exist these should still be to the benefit of all. Rawls (1973) formulated two principles of justice to ensure fair distribution of social goods in a society. These principles state that:

1. "Each person is to have an equal right to the most extensive total system of basic liberties compatible with a similar system of liberty for all".

2. Social and economic inequalities that do exist are to be arranged so that they can be reasonably expected to be to everyone's advantage and be attached to positions and office that are open to all.

The authors propose that these two principles of Rawls be used as a moral tool to develop general guidelines for resolving the tension between control and access to scholarly information with specific reference to developing nations.

According to the first principle all people are fundamentally equal, have equal intrinsic human rights together with the freedom to exercise them without infringement on the similar rights of others. These basic rights ought to form the foundation of the fair distribution of social goods in society. The right to access to essential information (i.e. the common or public good category) can be seen as such a basic right because of its essential nature in satisfying all basic rights and as such should be taken into account in the development of any IPRs system. IPRs must therefore ensure that each person at least has access to the minimum information to satisfy essential needs. Failure to do so can be said to be a form of information injustice. According to Kingma (2001), there are various mechanisms to ensure fair 
distribution of essential information, including government subsidies through taxation, donations, and advertising. For poor and developing nations this normative guideline is of even more relevance in order to ensure access to essential information.

The second principle implies that certain information goods can be treated as commodities, i.e. as private goods, and be distributed and used unequally in a society. Thus fair compensation for authors through IPRs is accommodated and the inequalities arising out of the competitive value of information justified. But there are some provisos: first, such information ownership rights are allowed only when it is to the benefit of all (Rawls, 1973). Should this not be the case, it is unjust. Second, there should at least be equal opportunities for everyone to access essential information and have the opportunity to contribute as a creator of information goods. Last, the permissible inequalities are always secondary to the first principle (Rawls, 1973). The authors are therefore arguing that the right to access to essential information (common good) can and must take precedence over the right to ownership of information (private good).

Applying Rawls' two principles the imbalance between the common and private good, or access and ownership, must be restored in terms of information goods. This would reflect the dual purpose of IPRs and will allow for a more equitable intellectual property regime appropriate for developing nations. In terms of the earlier metaphor, the ground conceded to the common good need to be reclaimed as depicted in

Figure 2.

Figure 2: Restoring balance between common/public \& private good

The following two guidelines can be presented to ensure the fair and just distribution of essential information to developing countries:

- Since the right of access to essential information is more important than the right to ownership, IPRs should protect information as a common good (also referred to as the information commons) and ensure that the

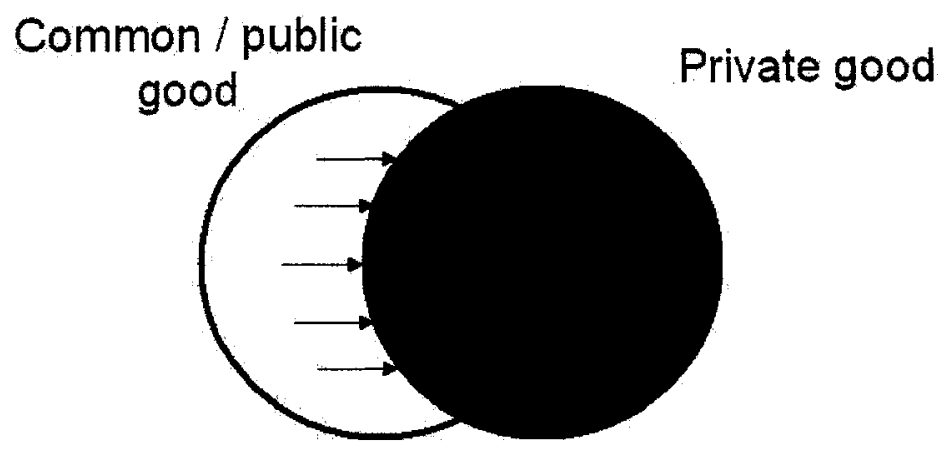


information needed to satisfy basic needs, such as agriculture and education, is distributed in such a manner that everyone has access to it and an equal opportunity to benefit from it. In developing countries, this aspect is of particular importance in the cases of indigenous knowledge that have become subject to IPRs.

- Creators and distributors of information goods can claim moral and economic rights on the conditions that these rights:

- Do not prevent creativity;

- Shrink the gap between the information rich and poor; and

- Ensure fair compensation for the original creators. Again, this is of vital importance to developing countries when it comes to indigenous knowledge.

\section{CONCLUSION}

In this paper, it was argued that the distribution of scholarly information must be fair in the marketplace. It is based on the view that education is essential and that people cannot be excluded from access to educational material, including scholarly publications. It was furthermore argued that the current trend in IP legislation favours the stricter control of access to scholarly material. This poses the moral question of the fair distribution of scholarly information in the marketplace. Based on the social justice theory of John Rawls it was argued that access to scholarly information is essential and more important than the right to own or protect it.

\section{REFERENCES}

Bates, B.J. (1988), Information as an Economic Good: Sources of Individual and Social Value. In: The Political Economy of Information, ed. Mosco, V. and Wasko, J. Madison, Wisconsin: The University of Wisconsin Press, pp. 76-94.

Branscomb, A. W. (1994), The Economics of Information-Public and Private Domains of Information: Defining the Legal Boundaries (adapted from the keynote address presented at the 1994 ASIS annual Meeting in Alexandria, Virginia), online at http://www.asis.org/Bulletin/Dec-94/branscom.html accessed 17.02. 2005

Britz, J. J. (1999), Access to Information: The ethical challenges to the information era. In: The Ethics of Electronic Information in the Twenty-First Century. Century. Ed. Pourciau, L. West Lafayette: Purdue University Press, pp. 9-29.

Lor, P.J. \& Britz, J.J. (S.a.), Knowledge production, international information flows and intellectual property: an African perspective. International Information and Library Review. In press.

Du Plessis, E. (1999), Intellectual property and intellectual freedom. The Moral and Legal Challenges of the Information Era, University of Pretoria, Pretoria, South Africa, 24-25 May 1999. 
Du Toit, A.S. (1994), Developing a price strategy for information products. South African Journal of Library and Information Services, 62 (4): $162-167$.

Hamelink, C. J. (1999), Digitaal Fatsoen: Mensenrechten in Cyberspace. Amsterdam: Boom.

Kingma, B. R. (2001), The Economics of Information: A Guide to Economic and CostBenefit Analysis for Information Professionals. Littleton, Colorado: Libraries Unlimited.

Lara, G. (1998), The Piracy of American Films in China: Why the U.S. Art Form is not Protected by Copyright Laws in the People's Republic of China, UCLA Journal of International Law And Foreign Affairs 2(2):343-352.

Lehman, B. (2002), Key Report Sends Developing Countries a Distorted Message on IP Rights. Legal Times, accessed online 12.02.2005 at http://www.IPRscommission.org/graphic/Views articles/Legal Times.htm

Maskus, K.E. (2000), Intellectual property rights in the global economy. Washington, D.C.: Institute for International Economics.

Maxwell, T. (2004), Is copyright necessary? First Monday 9(9), online at http://firstmonday.org/issues/issue9 9/maxwell/index.html accessed 15.02. 2005.

Media Trade Monitor. (2005), UNESCO Convention on Cultural Diversity, online at http://www.mediatrademonitor.org/taxonomy/page/or/30 accessed 21.01.2005

Ponelis, S. R. and Britz, J. J. (2004), Teaching Information Economics to Undergraduate Information Science Students at the University of Pretoria. South African Journal of Information Management, December 2004, 6(4).

Prakash, S. (1999), Towards a synergy between biodiversity and intellectual property rights. Journal of World Intellectual Property, 2(5).

Rawls, J. (1973), A Theory of Justice. Cambridge: The Belknap Press of Harvard University Press.

Rowley, J. (1997), Principles of price and pricing policies for the information marketplace. Library Review, 46 (3): $179-189$.

Sabbagh, D. (2004), Reed Elsevier chief hits back in scientific publishing row. Times Online, online at http://business.timesonline.co.uk/article/0,9071-1204570,00.html accessed 17.01.2005

Scholars for dollars. (2004), The Economist, December $11^{\text {th }} 2004$, p. 55.

Shapiro, C. and Varian, H. R. (1998), Versioning: The Smart Way to Sell Information. Harvard Business Review, November-December 1998: 106-114.

The triumph of the commons. (2005), The Economist, February $12^{\text {th }} 2005$, pp. 55-56.

Varian, H. R. (1998), Markets for Information Goods, online at http://www.sims.berkeley.edu/ hal/Papers/japan/index.html accessed 17.02.2005

Who pays the piper... (2005), The Economist, February $12^{\text {th }} 2005$, pp. $70-72$.

WIPO. (2004), Proposal by Argentina and Brazil for the Establishment of a Development Agenda for WIPO (WO/GA/31/11). WIPO General Assembly, Thirty-First $\left(15^{\text {th }}\right.$ Extraordinary) Session, Geneva, September 27 to October 5, 2004. 